\title{
La producción vinícola en el mundo fenicio-púnico. Apuntes sobre cultivo de la vid y consumo del vino a través de las fuentes arqueológicas y literarias
}

\author{
Fernando Prados Martínez ${ }^{1}$ \\ Universidad de Alicante \\ fernando.prados@ua.es
}

\section{RESUMEN}

En este artículo se pretende realizar un estado de la cuestión sobre el conocimiento del cultivo de la vid en el mundo de Cartago y sobre la producción y exportación de vino a través de las fuentes arqueológicas y literarias. Para ello, nos apoyaremos en las referencias extraídas de diversos textos clásicos púnico-romanos (Magón, Virgilio o Columela) y en datos obtenidos a partir de la realización de excavaciones arqueológicas tanto en Cartago como en su entorno próximo. Además, para complementar la información, vamos a estudiar la presencia de semillas de Vitis vinifera detectada en diversos análisis polínicos realizados en contextos excavados recientemente.

Palabras clave: fenicios, púnicos, vino, viñedos, producción y comercio.

Wine production in the phoenician and punic world.

Notes about wine culture and consumption through the archaeological and literary sources

\begin{abstract}
In this article we will make an analysis on the knowledge of vineyard in the world of Carthage and the production and export of Phoenician and Punic wine through the archaeological and literary sources. We must rely, therefore, references to classic texts (Mago, Virgilio Columela) and data from archaeological excavations in Carthage and its environment. In addition, to complement the information, we will also study the presence of grape seeds -Vitis vinifera- into the botanical analysis of some archaeological places.
\end{abstract}

Key words: Phoenicians, punics, wine, vineyard, production and trade.

\footnotetext{
${ }^{1}$ Área de Arqueología. Universidad de Alicante. Campus de San Vicente del Raspeig. Apartado de Correos 99-03080 (Alicante). E-mail: fernando.prados@ua.es 


\section{Cartago y la herencia cultural fenicia. Sucinto análisis histórico}

Cartago, la celebérrima metrópolis definida por la historiografía de los siglos XVIII y XIX como "Madre Mediterránea" había sido fundada por colonos tirios a finales del siglo IX o a principios del VIII a.C. ${ }^{2}$ La ciudad disfrutó, desde mediados del siglo VI a.C., de un gran despegue económico palpable en su registro arqueológico, en el que se vislumbran cambios importantes vinculados con la intensificación del comercio de larga distancia. La razón primordial de este crecimiento fue, curiosamente, un hecho aparentemente trágico: la conquista de la que hasta entonces había sido su metrópolis, Tiro, por parte del poderoso ejército de Nabucodonosor II de Babilonia. La ciudad norteafricana se transformó en una gran polis de carácter comercial y fue adquiriendo importancia a través de una política exterior tremendamente agresiva que se encaminó a asegurar las rutas y los territorios de mayor interés para el desarrollo de su empresa económico-comercial mediante el desarrollo de una fuerte política colonial, definida por algunos estudiosos como imperialista (López Castro, 1991, 87).

El siglo VI a.C. supuso la transformación del modelo económico y social que había permanecido en las franjas costeras del Mediterráneo Occidental desde la llegada de los primeros colonos fenicios hacia finales del siglo IX a.C., caracterizado por la interacción con los pueblos indígenas y la coerción más o menos violenta según los casos. A la llamada por la historiografía al uso "crisis del siglo VI a.C.", con la caída de Tiro como causa más o menos remota, hemos de añadir una serie de sucesos históricos coincidentes cronológicamente en Occidente. Entre ellos, el colapso del sistema económico de Tartessos que se apreció en la caída del comercio de metales, el decrecimiento de la producción en Gadir y los continuos abandonos de centros poblacionales desde el 600 a.C. por todo el Mediterráneo occidental. Estos hechos desembocaron en la total independencia de Cartago que rápidamente se puso al frente, de forma hegemónica, de todas las fundaciones fenicias arcaicas que sobrevivían aún, aupándose como nueva metrópolis. En la organización de la sociedad cartaginesa se reflejó la fenicia, así pues, la sociedad se organizó en torno a los comerciantes y los artesanos. En pocos años, Cartago se convirtió en un puerto internacional de primera magnitud, ubicado en una posición estratégica inmejorable.

La aparición de esta ciudad norteafricana y su posición hegemónica no conllevó, al menos en principio, grandes movimientos de población (se mantuvo un amplio contingente de población de origen fenicio en las principales fundaciones semitas arcaicas). Sí se llevaría a cabo, por el contrario, un trasvase de población a pequeña escala, a nivel de elites gobernantes procedentes del norte de África, con lo que afloró el elemento semita como rasgo distintivo (López Pardo y Suárez, 2002). Estas cuestiones provocaron la adopción por parte de muchos colonos de origen fenicio establecidos en la costa desde hacía varias generaciones de un modo de vida sociopolítico definido como púnico, que se erigió de una manera simultánea en la mayoría de los territorios costeros del Mediterráneo central y occidental.

2 Entre los materiales más antiguos de la ciudad destacan un conjunto de fragmentos de cerámicas griegas pertenecientes al periodo geométrico (primera mitad del siglo VIII a.C.) que han generado un interesantísimo debate científico sobre los orígenes y la fundación de la ciudad, fechada en el 814 a.C. según la leyenda mítica (Morel, 1999, 11) 
Siguiendo con este análisis sucinto de la historia comercial de Cartago, en Sicilia, a principios del siglo VI a.C., se inició una oleada de agresiones contra los centros fenicios por parte de sus rivales comerciales, los griegos, que quisieron aprovechar el momento de inestabilidad provocado por la toma de Tiro. Estas acciones fueron las que provocaron la intervención de Cartago, que arbitró las cuestiones políticas y económicas de los antiguos centros fenicios que además habían requerido su ayuda. En relación con esto se sabe que gran parte de estas poblaciones no contaban con un contingente militar importante, ni les interesaba mantenerlo, pues sabían que podían contar con la ayuda de las tropas de Cartago que se erigió como protectora de todos sus aliados. La presencia de los cartagineses en las islas durante largos periodos de paz supuso la aceleración de los procesos de aculturación. Durante estos lapsos de tiempo, la sociedad púnica adquirió influjos helenísticos que fueron claves para su evolución y desarrollo posterior.

En Cerdeña, las causas de la penetración púnica fueron las mismas que las de la anterior presencia fenicia; la enorme riqueza de la isla en materias primas, especialmente hierro y plomo argentífero. También aquí las causas bélicas y el antagonismo entre púnicos y griegos supusieron la entrada y el posterior establecimiento de los cartagineses. La acción de los griegos no sólo ponía en peligro a las antiguas ciudades fenicias, sino que sobre todo dificultaba el comercio a través de las rutas marítimas históricamente dominadas por los semitas. El control púnico de la isla de Cerdeña fue absoluto, al contrario del que mantuvieron en el oeste de Sicilia. Para asegurar el control de la isla levantaron fortificaciones y un complejo sistema de vigilancia con aspectos técnicos novedosos y adaptados, en mayor o menor medida, a los preexistentes de origen sardo-nurágico y fenicio arcaico. Así pues, se ocupó el espacio geográfico con contingentes militares, con población civil y además se explotó comercialmente. Buenos ejemplos de esta intensa política defensiva la tenemos en la región del sulcitano, al suroeste de la isla, donde se organizaron diversos complejos militares en torno a Slky (Sulcis) tales como Pani Loriga o Monte Sirai.

Para el caso de la Península Ibérica, tan sólo podemos pensar en un interés imperialista cartaginés durante la etapa de control bárquida, en plena Segunda Guerra Púnica, en la que se fundaron nuevos centros urbanos, se realizaron aportes importantes de población y se explotaron sistemáticamente los recursos naturales. De todas formas Cartago se erigió como "protectora" de los intereses comerciales de los fenicios occidentales desde el 510 a.C. con el establecimiento de lo que ha sido definido como "liga púnico-gaditana" (Arteaga, 1994) y cuando se reconoció, en el Primer Tratado Romano-Cartaginés, el monopolio comercial púnico en el Mediterráneo y principalmente ya desde el tratado del 348 a.C. cuando, además del control comercial, se prohibió a los romanos y a sus aliados la fundación de colonias en el Extremo Occidente. En la Península, pues, debemos pensar en el desarrollo de una hegemonía política y económica de la ciudad norteafricana sobre las antiguas fundaciones fenicias. De la expansión cartaginesa por el Mediterráneo surgió todo un conjunto de población caracterizada por el fenómeno del mestizaje, a la que sucesivamente se iban incorporando nuevos grupos humanos, procedentes del norte de África, con lo que se iba afianzando el elemento cultural púnico con la arquitectura o la lengua como algunos de sus rasgos propios y diferenciadores (Prados Martínez, 2003, 198). 
Así pues, desde este momento comienza a generalizarse una cultura púnica por todo el Mediterráneo central y occidental. Ésta se extendió tanto a través de nuevas fundaciones y ocupaciones de territorios no ampliamente poblados, tales como el área costera de la Península Ibérica o la costa de Argelia, como a través de la influencia directa sobre territorios de gran tradición cultural. Dichos territorios eran establecimientos antiguos de poblaciones indígenas, de colonos procedentes de oleadas migratorias del norte de África o de la primera gran presencia comercial fenicia, desde el siglo VIII a.C.

Ponerle fin a la historia de Cartago es bastante más complicado de lo que a priori podría parecer conociendo como se conoce la fecha de la destrucción de la ciudad por las tropas romanas de Escipión en 146 a.C. Decimos que la fecha que supone el final de la cultura cartaginesa es difusa, porque no existe realmente esa fecha; no podemos afirmar que con la destrucción de la ciudad en el 146 a.C. y con el final de la Tercera y última Guerra Púnica desapareciese una cultura tan rica y arraigada. Pese a la potente "maquinaria" cultural romana, los antiguos territorios dominados por Cartago mantuvieron viva la lengua, las instituciones municipales, las creencias y las manifestaciones religiosas durante varios siglos después de la destrucción de la ciudad de Dido.

\section{La agricultura y la viticultura en el mundo púnico: la herencia oriental y las fuentes textuales}

Tras esta breve aproximación histórica al mundo de Cartago, nos adentraremos ahora en el tema objeto de análisis a lo largo de estas páginas que no es otro que la viticultura púnica y el consumo y producción de vino. Cabe reseñar que están bastante mejor atestiguados la producción, el comercio y el consumo del vino en el mundo fenicio oriental que en el occidente fenicio y púnico. Pese a la falta de restos materiales, esta laguna puede ser subsanada mediante el análisis detallado de las fuentes textuales y el estudio de los contenedores -las ánforas- cuyo registro ofrece datos de primera mano sobre el comercio de la apreciada bebida entre los distintos territorios dominados directamente por Cartago o ubicados en su área de influencia. La existencia también de algunos núcleos industriales en los que se pueden identificar espacios tipificados concretos dedicados a la elaboración del vino ayudan también a dibujar un panorama de la producción vitivinícola fenicia y púnica. Asimismo, recientes estudios paleobotánicos han ofrecido datos concluyentes sobre el cultivo de la vid en estos mismos ambientes.

La viticultura, que era conocida desde los primeros momentos de la presencia fenicia, no tuvo, por el contrario, desarrollo hasta aproximadamente el siglo IV a.C., en la llamada plena fase helenística. Los análisis palinológicos llevados a cabo en las proximidades de los puertos de Cartago, donde aparecieron restos de Vitis vinifera domesticada hacia mediados del siglo IV a.C. (Zeist y Bottema, 1982, 19) son clarificadores en este sentido. La inclusión de la capital púnica en los circuitos culturales helenísticos junto con la conquista de la parte occidental de la isla de Sicilia, trajo consigo no sólo la adopción de la fenomenología religiosa griega, sino también la de 
muchos rasgos culturales egeos entre los que estaba el consumo del vino por parte de las elites o clases privilegiadas.

Desde el siglo V a.C. algunas referencias textuales griegas nos describen las riquezas naturales del territorio cartaginés: "Enfrente de su país, dicen los cartagineses, hay una isla llamada Kerkena, de doscientos estadios de longitud, pero de poca anchura, donde pueden pasar caminando desde el continente, llena de olivares y viñas"(Heródoto IV, 195). Por su parte, Diodoro de Sicilia, narrando la acción contra Cartago de Agatocles, el célebre tirano de Siracusa, escribió: "Agatocles condujo la armada a Megalópolis (Cartago). Todo el país que hacía falta atravesar estaba repleto de vergeles irrigados por fuentes y canales numerosos, casas de campo bien construidas y pintadas por cal que bordeaban la ruta y mostraban la riqueza... los terrenos estaban cultivados de viñas, olivos y árboles frutales, bueyes, corderos y caballos..." (Diodoro de Sicilia, XX, 8, 2-3-4). Polibio evocó las "numerosas granjas magnificamente equipadas..." en un texto que hace referencia a la I Guerra Púnica, durante la penetración por la misma zona del ejército del cónsul romano Régulo, en el 256 a.C. (Polibio I, 29, 6-7) y Timeo señaló cómo "los cartagineses mandaron cortar frutales y viñedos de Sicilia y prohibieron plantar otros, para asegurarse así el monopolio" (referencia recogida en Pseudo-Aristóteles, De mirabilibus auscultationibus, 100).

Si nos centramos, por ejemplo, en los textos de Polibio, todo parece indicar que los cartagineses abandonaron el cultivo de cereales en su propio entorno potenciando el de los frutales y la viña, ya que disponían de sus propias posesiones territoriales -Sicilia, Cerdeña y Libia- que funcionaban como sus graneros principales y fuentes de abastecimiento de la metrópolis y su territorio circundante, donde existían otras ciudades importantes y núcleos poblacionales potentes como Kerkouane, Kurubis, Aspis, Uthina o la propia Utica. Otras citas aluden directamente al consumo del vino en el mundo cartaginés, como una que Platón puso en boca de Clinias el Ateniense, quien suscribía una prohibición cartaginesa contra el consumo de vino por ciertas clases sociales como los soldados en campaña, los magistrados y jueces durante las sesiones, los capitanes de barco, las parejas que deseaban procrear, los ciudadanos durante las horas del día y todos los esclavos (Platón, Leyes, 674 A). Idéntica proclamación fue citada también por Aristóteles en alguno de sus textos en referencia también a la política cartaginesa en este sentido (Aristóteles, Económica, I, V, 2, 1344).

Si generalmente se vinculó el desarrollo de la agricultura púnica como natural continuación de la que habían realizado los fenicios, para otros autores la agricultura no tuvo importancia para éstos y fue abandonada; este el caso de Cicerón, que afirmó que el verdadero sustento de los cartagineses fue siempre el comercio marítimo y que probablemente Cartago encargó a otros la producción de cereales. Cicerón llegó a afirmar que "nada ha contribuido más a la lenta decadencia y la caída de Cartago y Corinto que los viajes en todas las direcciones de sus ciudadanos, que no se detuvieron a cultivar sus campos.." (De Re Publica). En cambio, mencionó la recomendación a un granjero durante una inspección de terrenos de estudiar a fondo la obra de Magón: “...Magonis Carthaginiensis sunt libri perdiscendi” (Cicerón, De Oratore 1,249) lo cual resulta incongruente por otro lado. A pesar de lo escrito por Cicerón, la agricultura cartaginesa debió tener gran envergadura, ya que fue clave 
en la recuperación económica de la ciudad tras las Guerras Púnicas, periodos en los que tanto la navegación como el comercio a larga distancia fueron completamente inexistentes por el cumplimiento de las estipulaciones y las cláusulas de los tratados de paz firmados con Roma.

\section{El desarrollo de la agronomía púnica: la obra de Magón y sus "discípulos" latinos}

La clave para el conocimiento teórico de la agronomía cartaginesa es el tratado de Magón (fechado según parece hacia finales del siglo IV y principios del III a.C.) que se conoce a partir de las traducciones realizadas por griegos y latinos. Dichas traducciones, que se llevaron a cabo desde el momento mismo de la conquista, supusieron un aporte fundamental para la agronomía romana, que alcanzó un gran desarrollo y esplendor. La obra de Magón tuvo una gran envergadura y sus veintiocho libros, desde luego, se asemejaron bastante a una enciclopedia sobre el mundo agrícola, al que se acercó desde numerosas perspectivas. Parte de la importancia de la obra radica en las numerosas traducciones que de ella se llevaron a cabo y en la cantidad de citas realizadas por todos los agrónomos de la antigüedad como Varrón, Columela, Plinio, Gargilus Martialis, Paladio y el autor de las Geoponica ya en época altomedieval. También el tratado de Magón es fundamental porque es uno de los escasos textos púnicos con los que se cuenta.

La obra se conoce fundamentalmente a través de las continuadas citas de dos de los más grandes agrónomos latinos, esto es, Varrón y Columela. Para el primero, la obra de Magón fue la suma de todos los conocimientos y, probablemente, esa fue su auténtica naturaleza, es decir, una compilación de datos recogidos desde un conocimiento de la tradición agronómica desarrollada en el entorno de Cartago desde época fenicia, bien oral o escrita. Varrón (116-27 a.C.) prestó una admiración extrema a este probable miembro culto de la nobleza púnica afirmando: "Uerum tamen ut carthaginiensem Magonem rusticationis parentem maxime veneremur" (Rerum Rusticarum libri I, 1.13).

Magón fue, según nos acercan estos autores clásicos, el creador de la agronomía en sentido amplio, incluyendo aspectos tales como los cultivos, la economía rural, la gestión mercantil de los productos agrícolas, las herramientas, la mano de obra e incluso alguna receta de cocina. Evidentemente Magón no los inventó, sino que fue el primero capaz de realizar una obra de síntesis y en ver la agronomía como una disciplina autónoma (Bendala, 2002-2003; Martin, 1971, 45).

Resulta extraño ver cómo el Senado Romano, que se había encargado de aniquilar Cartago en el 146 a.C., incluso procediendo a repartir los miles de ejemplares de la gran biblioteca de la capital púnica entre los reyes númidas que conocían la lengua, hiciese traducir al latín los veintiocho libros del célebre agrónomo (una traducción a la lengua latina, realizada por Décimo Silano, que fue seguida por otras tres al griego). El propio Plinio dijo "El senado ha decidido que Magón sea traducido aunque Catón haya escrito ya su De Agricultura" (HN, XVIII, 5). Además, cabe señalar la 
importantísima influencia que durante casi un siglo ejerció el tratado de Magón sobre la economía rural de Roma, justo hasta la reforma agraria promovida por los Graco.

La "latinización" del texto original cartaginés se conoce incluida en tres textos: el primero de ellos se encuentra en el principio de las "Res Rusticae" de Varrón, que comienzan con una bibliografía de más de cincuenta nombres de autores griegos que concluye con una frase “...pero la celebridad de Magón el cartaginés supera a todos: escribiendo en lengua púnica, ha tratado temas diversos en veintiocho libros que Cassius Dionysius de Utica ha traducido en veinte libros ...". Columela, nacido en Cádiz, ciudad culturalmente púnica, a principios del siglo I d.C., citó la misma lista bibliográfica cambiando el sentido y mencionando a dos traductores al griego de Magón, llamados Dionisio de Utica y Diófanes de Bitinia, declarando que el más venerado por él es el cartaginés. Columela recogió al inicio de su obra un consejo extraído del texto del cartaginés:

"Quien ha comprado tierras en el campo debería vender su casa en la ciudad, de ese modo no deseará adorar a los dioses urbanos del hogar en lugar de a los del campo. Quien prefiera su residencia en la ciudad no necesita terrenos en el campo"

Columela, De Agricultura I, 1.18

De Magón, por otra parte, se conoce bastante poco. Algunos autores lo han relacionado con la familia de los magónidas, que instituyeron el imperio cartaginés en el siglo VI a.C., pero en realidad, para la gran parte de los investigadores se trató de un personaje que vivió en época helenística. R. Martin (Martin, 1971) lo encuadra a finales del siglo IV a.C. mientras que en el Corpus de Agrónomos Latinos de Speranza se le relaciona con un Magón, hermano de Aníbal, que combatió en Hispania y en el norte de Italia. Lo que se acepta comúnmente es que se trató de un miembro de la nobleza o un gran terrateniente profundamente helenizado y que debió jugar un importante papel en el campo militar (Columela, XII, 4, 2; Plinio, HN, XVIII, 5). Conocemos también, y una vez más gracias a Columela, que Cartago había tenido otros tratadistas sobre Agronomía "praecepta rusticationis plurima tradiderunt Poeni ex Africa scriptores" (De Re Rustica, I, 1, 6) así, Magón pudo ser simplemente un gran recopilador de datos y de tradiciones. La obra está consagrada fundamentalmente a la arboricultura y, aunque se perdió, de ella conservamos 66 fragmentos gracias a las menciones realizadas en las obras de Varrón, Plinio, Columela y Paladio.

Del tratado de Magón, además, extraemos una magnífica receta para la confección de un vino dulce, elaborado a partir de uva pasa, que tendría después gran aceptación en el mundo romano; se trata del célebre passum, algo similar a un vino de postre que consumimos hoy en España, conocido con el nombre de la variedad de uva con la que se confecciona, la Pedro Ximénez. Columela (XII, 39) escribe la clave para la obtención de esta receta cartaginesa: "hemos de poner los racimos a secar al sol en una superficie plana durante los seis días antes de su prensa". Se trata, sin duda, del mismo proceso que se desarrolla hoy día para la realización de vinos dulces y densos de postre exponiendo los racimos de uva al sol para su oxidación antes de proceder a su pisado. 
Algunos datos fundamentales sobre el cultivo de la vid aparecen también en la obra de Columela reflejando los conocimientos de la obra del agrónomo púnico. En dichos escritos se menciona cómo ha de ser, por ejemplo, la plantación de las viñas (De Re Rustica, III, 10, 3 y III, 12, 5) ubicadas en laderas inclinadas expuestas hacia el norte. Parece ser que Magón aconsejaba airear las raíces de los viñedos colocando entre ellas algunas piedras (según indica Columela, III, 15, 4). También el poeta y agrónomo Virgilio en su obra Geórgicas utilizó numerosos datos de la obra de Magón, aunque los tomó como propios y tal fue la admiración que por el cartaginés tuvo Columela que delató a Virgilio, acusándolo de plagio, señalando que sus escritos sobre la protección de la viña habían sido tomados de Magón: "Hi uidentur, ut Mago prodit, et aquas hiemis et uapores aestatis propulsare radicibus; quem secutus Vergilius tutan semina et muniri sic praecipit..." (De Re Rustica, III, 15, 4)

El tratado de las Geoponicae, realizado en el siglo X, reúne textos de una treintena de autores griegos y latinos algunos de ellos traductores y abreviadores de la obra de Magón, con numerosas referencias a la viña y a la vinificación (Capítulos V, 7; V, 31; V, 45; VI, 12; VII, 3 y VII, 17).

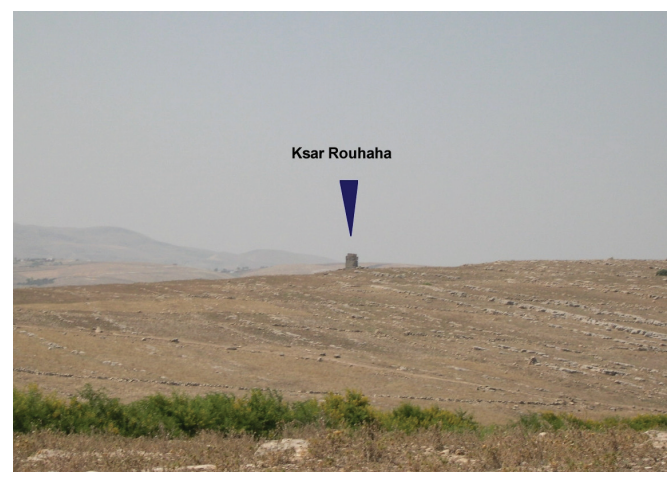

Fig. 1: El monumento turriforme púnico de Ksar Rouhaha visto desde Ksar Chenane (Hédil, Túnez). En medio, la vegetación indica el pequeño uadi que delimita las diferentes propiedades

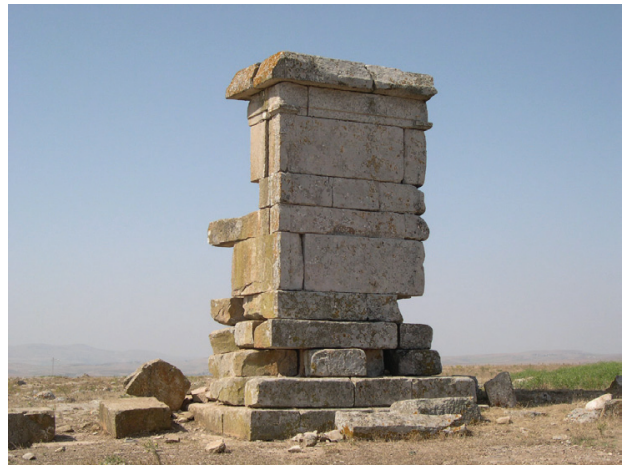

Fig. 2: El monumento turriforme de Ksar Chenane (Hédil, Túnez) hito en el paisaje rural de la comarca

La enciclopedia agraria de Magón fue concebida, en definitiva, para un público culto, para una clase de grandes propietarios de terrenos fértiles en los alrededores de Cartago que mediante un sistema esclavista se ocuparon de la viticultura y la arboricultura. Magón aconsejó a estos grandes propietarios que abandonasen la ciudad y que se trasladasen a vivir a sus villas rurales, de manera que pudiesen controlar directamente la producción y el desarrollo de las actividades agrícolas. También abogó por las inversiones agrícolas a largo plazo, para las que debió de ser fundamental la existencia de grandes propiedades de terreno. La existencia en algunas regiones del entorno de Cartago como la de Hédil, ubicada entre el río Medjerda y el Millian, 
de monumentos turriformes de carácter funerario ubicados en zonas elevadas ${ }^{3}$, con relación visual entre ellos y dominando amplias superficies agrícolas separadas por pequeños cursos de agua entre sí, indican la existencia de grandes propiedades dominadas por señores que mediante la construcción de los monumentos funerarios o cenotáficos que funcionaron, sin duda, como marcas de propiedad, se aseguraron el control efectivo e ideológico de las mismas (Prados Martínez, 2008). De este modo se empleó el simbolismo del edificio vertical como un instrumento de control sobre los campesinos y la mano de obra servil y, a la vez, como la máxima expresión de la posición social de la familia en relación con sus iguales, a través de la demarcación, con estos hitos monumentales, de las propiedades limítrofes (Figs. 1 y 2).

\section{Las fuentes arqueológicas: producción, villas rústicas, lagares y almacenes}

Las residencias rurales que se han excavado en Túnez (Fantar, 1984, 4; Fantar, 1985, 13) presentan esquemas bipartitos, con la zona residencial, que estuvo ocupada por el rico terrateniente y su familia, a un lado, y la zona de uso industrial, una clase de pars frumentaria con almazaras y con pithoi y dolia encastrados en el suelo y depósitos revestidos de opus signinum para contener vino y aceite, al otro. Dos de estas villas han sido excavadas en Gammarth, muy cerca de Cartago. La Villa de la Baie des Singes, que fue prácticamente destruida por una máquina excavadora, proporcionó datos sobre este tipo de asentamiento rural a las afueras de la capital. Se recuperaron una serie de estancias de planta rectangular, con presencia de hornos de pan y ánforas de tipo grecoitálico (que fechan el abandono de la vivienda en torno a los primeros años del siglo II a.C., al final de la Segunda Guerra Púnica) con cisternas y piletas recubiertas de hormigón hidráulico (Fantar, 1985, 14) similares a otras exhumadas en otros centros púnicos del Mediterráneo occidental que mencionaremos más adelante y que estuvieron dedicadas al prensado de la uva y a la recogida del mosto resultante.

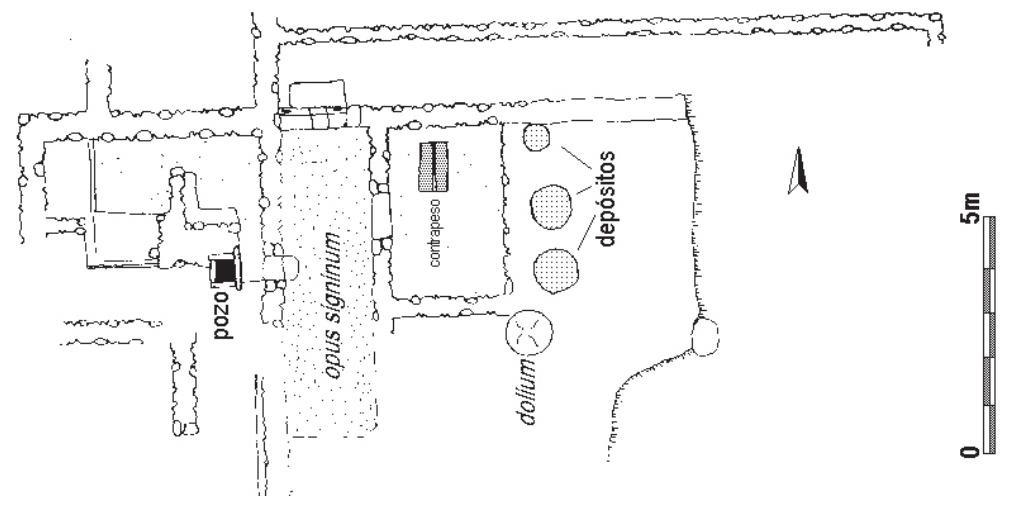

Fig. 3: La villa rural púnica de Gammarth, en las proximidades de Cartago (actualizado a partir de Fantar, 1985, 88)

${ }^{3}$ Caso de los de Ksar Chenane (Fig. 2), Ksar Rouhaha (Fig.1) o Ksar Bou Derhem. 
La otra "villa" rural o epaulis próxima a Cartago es la de Gammarth, que fue hallada de forma fortuita en 1967. La superficie total del edificio es de unos $200 \mathrm{~m}^{2}$, según apunta su excavador (Fantar, 1985, 14) y presenta un plan bipartito, con un área residencial, una especie de pars urbana, con sala de baño y estancias abiertas a un patio con columnas y ricos capiteles, y un sector industrial, suma de una pars rustica y una pars frumentaria -siguiendo la terminología de las uillae romanas- de producción y almacenamiento de productos agrícolas (Fig. 3). Presenta unas estancias a diferentes alturas y de nuevo unos espacios con plantas rectangulares utilizados como almacenes. Otras estructuras exhumadas han sido pozos circulares y piletas recubiertas de opus signinum y lo que el excavador ha interpretado como una almazara, por la presencia de contrapesos. Asimismo, el edificio pudo estar dedicado también a la producción de vino, como se ha indicado por el tipo de contenedores encastrados en el pavimento y por las piletas, a falta de analíticas que serían determinantes en este sentido (Fantar, 1985, 21). Por otro lado, las prensas, que estarían realizadas en madera como en época romana, no se han conservado aunque sí las trazas de su uso. La última utilización del edificio, según apuntan los materiales del estrato de abandono, fue a mediados del siglo II a.C. y para su excavador pudo ser destruido y abandonado en el momento de la incursión de Escipión Emiliano en el 146 a.C. que conllevó, como sabemos, la destrucción de la metrópolis púnica.

En los alrededores de Cartago, en la zona denominada Megara por las fuentes, se han excavado otras instalaciones rurales de plan bipartito con la zona residencial separada de la que estaba destinada a funciones agrícolas (Fantar, 1996, 119). La ubicación de estas villas rurales en el entorno de la ciudad de Cartago nos permite conocer mejor los modelos de ocupación y explotación del territorio extraurbano con anterioridad a la conquista romana. Estas fincas rurales, que tuvieron probablemente torres de control y vigilancia o sectores sobre-elevados (Prados Martínez, 2008), estarían dedicadas a la producción agrícola y estarían controladas directamente por elites urbanas que habitaban en la ciudad o en residencias ubicadas en su entorno inmediato.

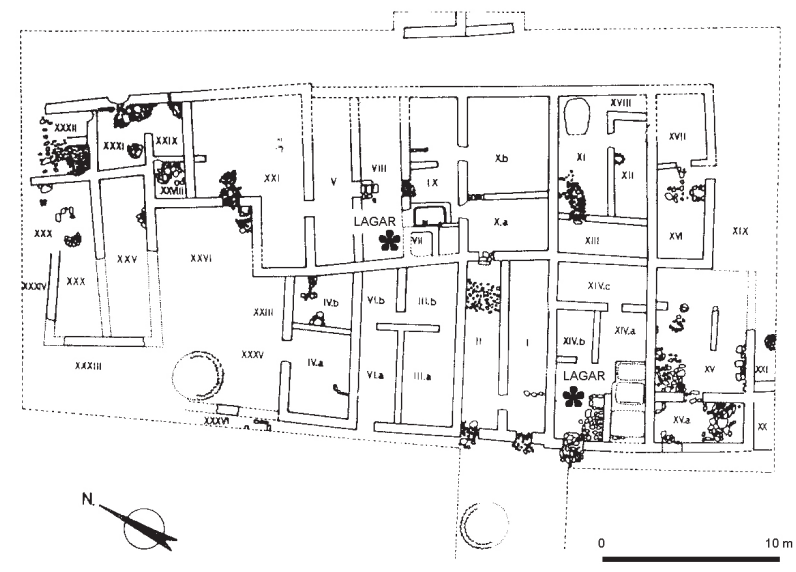

Fig. 4: El poblado de Las Cumbres (Puerto de Santa María, Cádiz). Los asteriscos señalan los dos lagares (según Ruiz y Pérez, 1995, 110) 
Dentro de estas granjas-torre podemos encuadrar la que menciona Apiano en su relato de la toma de Cartago durante la Tercera Guerra Púnica (Apiano, Lyb. 101) o la rus urbanum citada por Justino (Justino, 31,2). En el caso de la Península Ibérica son de sobra conocidas las instalaciones agrícolas denominadas recintos fortificados o fermes fortifiées (Moret, 1999, 59) que evolucionaron desde época tardopúnica hasta el periodo republicano en zonas de la campiña cordobesa, la comarca de la Serena extremeña o el Alentejo, ya en Portugal, y que han sido confundidas en alguna ocasión con las célebres torres anibálicas, citadas por Plinio, de carácter militar: spectat etiam nunc speculas Hannibalis Hispania terrenasque turres iugis montium impositas (Plinio, HN, 35, 169). Estas granjas tuvieron una parte elevada para controlar el terreno agrícola circundante y poseyeron, en algunos casos, almacenes y graneros con plantas tripartitas de tipo oriental. La existencia de estos modelos socio-económicos de granjas aisladas fue mucho más frecuente en las proximidades de los grandes centros habitados, caso de Porcuna, Puente Tablas o Torreparedones (Jaén) y anticiparon de manera directa la afloración posterior de grandes uillae romanas con pars rustica y pars urbana dedicadas a la explotación del olivo y la vid.
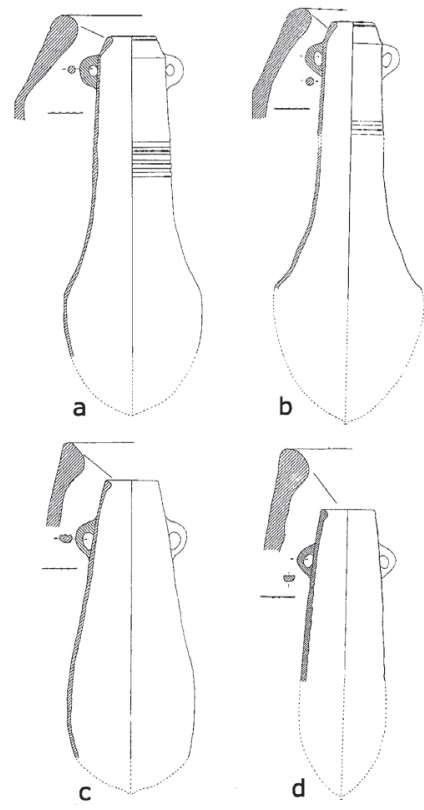

Fig. 5: Material anfórico asociado a los lagares del poblado de Las Cumbres; a y b, evolución local de la forma Mañá Pascual A4; c y d, evolución local de la forma Mañá A5 (Según Ruiz y Niveau, 1999)

Las dimensiones de los edificios, la tipología de las plantas y el carácter industrial de los mismos nos asemejan las estructuras vistas en las cercanías de Cartago con las que fueron excavadas en 1991 en una ínsula del Poblado de Las Cumbres (Fig. 4), próximo al Castillo de Doña Blanca (Puerto de Santa María, Cádiz) y fechadas en el siglo III a.C. (Ruiz Mata y Pérez, 1995, 106). En este yacimiento se han detectado estructuras claramente relacionadas con la producción de vino como son dos lagares con piletas similares a las de Gammarth, colocadas a diferentes alturas para el pisado de la uva y la conducción del mosto mediante pequeños canales. En el caso gaditano, 
las piletas estaban recubiertas también con opus signinum en el interior y aparecieron junto a ellas unas estructuras circulares encerradas por un pequeño muro con un pavimento de matriz arcilloso y fragmentos de ánforas que fueron empleadas para la fermentación y la cocción del mosto. El conjunto del lagar estaba conectado a un almacén ${ }^{4}$ y estaba formado por un total de tres piletas, dos sobreelevadas a la misma altura en las que se pisaría la uva y una tercera por debajo de éstas que recibiría el mosto a través de unos caños. Los materiales asociados a estas estructuras son fundamentalmente ánforas vinarias de manufactura local (Fig. 5).

También en el propio yacimiento del Castillo de Doña Blanca se localizó otro conjunto de piletas (Fig. 6) con la misma cronología que las anteriormente mencionadas, en este caso ubicado en el interior de las viviendas (Ruiz Mata, 1995, 198). Esta actividad productora en el marco geográfico de la Bahía de Cádiz en época púnica se completó con la afloración de pequeñas villas rurales en la campiña (como las vistas en el entorno de Cartago), enclaves modestos ${ }^{5}$ dedicados a la producción y elaboración de vino y aceite que, sin duda, dependieron política y administrativamente de centros mayores de carácter urbano, caso del propio Castillo de Doña Blanca (González Rodríguez, 1985, 90 y ss.).

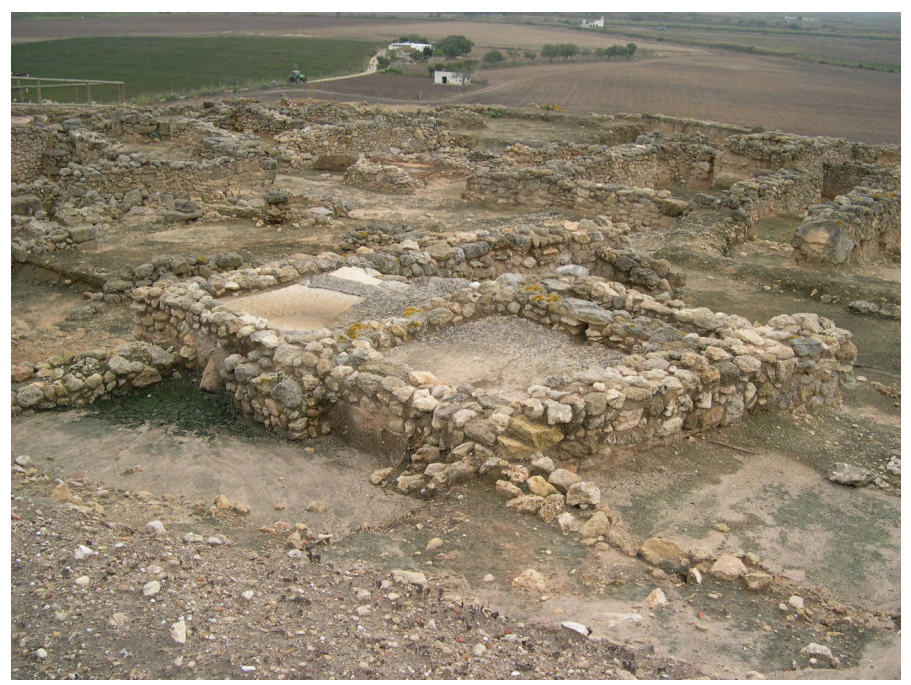

Fig. 6: Caserío púnico del Castillo de Doña Blanca; en primer término la zona de lagares

Otros testimonios arqueológicos del desarrollo de la viticultura en el mundo púnico los tenemos en el ámbito de las necrópolis, en las que se han constatado diversos elementos relacionados. Entre ellos destacan las pinturas parietales en el interior de hipogeos, en los que comúnmente se representan racimos de uva y otros elementos

${ }^{4}$ En el que aparecieron un amplio volumen de ánforas y lebrillos de gran tamaño.

${ }^{5}$ Como es el caso del Cerro Naranja (Jerez de la Frontera, Cádiz) un pequeño recinto de $1.300 \mathrm{~m}^{2}$ con un patio central rodeado de estancias que funcionaron como almacenes de ánforas y se fecha entre $350-275$ a.C. 
vegetales. También en excavaciones antiguas llevadas a cabo en Cartago aparecieron restos de frutos -uvas- en terracota que han aparecido formando parte de las ofrendas a los difuntos. Otros restos iconográficos han aparecido grabados, esculpidos y pintados, como en las estelas del tofet de Cartago, donde aparecen aperos de labranza y viñas.

Como indica Fantar $(1996,121)$ es probable que la escasez de restos epigráficos y de estelas en santuarios con alusión al vino pueda ser por causa del probable desprecio de los cartagineses hacia los trabajos del campo, efectuados por esclavos y que estarían totalmente devaluados para las clases sociales elevadas. Ahí puede estar la razón de las escasas imágenes de viñas en las estelas neopúnicas de Cartago y la no aparición de referencias en las monedas, al contrario de otras acuñaciones de la órbita púnica, como las de la ciudad de Lixus. Curiosamente en los muestreos de Lixus no ha aparecido indicio de Vitis, aunque el escaso porcentaje en general de los frutales identificados, documentándose tan sólo y de una forma minoritaria el olivo, hace pensar que se trató de un muestreo quizás reducido (Iborra et alii, 2003, 43) que dio cereal como el grupo más representado ( $85 \%$ del total de especies identificadas en las muestras). Por otro lado, aún queda mucho por hacer dentro de este campo, ya que han sido detectadas en prospecciones para la Carta Arqueológica de Túnez, de la que aún muchas hojas se encuentran en preparación por parte de un equipo del Instituto Nacional de Patrimonio, un conjunto de instalaciones junto a la frontera con Argelia talladas en la roca y que parecen lagares del tipo de los definidos como preindustriales por Greene (1996, 322).

Otros territorios que estuvieron dominados por los cartagineses o que estuvieron enmarcados geográficamente dentro de las regiones ubicadas en su órbita comercial y que presentan abundantes indicios de la existencia de un trasiego comercial constante con la metrópolis púnica sí que han ofrecido restos materiales relacionados con la producción de vino. El caso de la Península Ibérica es uno de los más evidentes; pensemos por un momento en el Alt de Benimaquía (Denia, Alicante) o en las posteriores estructuras ibéricas de Monravana (Liria, Valencia), el Castellar (Librilla, Murcia), La Illeta dels Banyets (El Campello, Alicante) con sus lagares similares a los de las Cumbres o Los Saladares (Orihuela, Alicante). También cabe señalar la excavación del pecio de El Sec, bajel cartaginés hundido en las proximidades de la costa mallorquina en el siglo IV a.C. y que contenía, junto con un cargamento bastante diversificado de cerámicas, numerosos sarmientos de viñas.

\section{Muestreos y analíticas: los hallazgos de taxones de Vitis vinifera en el ámbito feniciopúnico}

Uno de los rasgos más importantes para identificar el desarrollo de la viticultura en la Antigüedad viene determinado por la realización de análisis antracológicos de los restos de madera calcinados y paleocarpológicos de las semillas aparecidas en los sedimentos ubicados en contextos arqueológicos cerrados. Así, en algunos de los yacimientos feniciopúnicos más importantes del occidente mediterráneo se han obtenido datos de gran interés para confirmar la existencia de una cultura de la vid ya asentada desde época fenicia arcaica (siglos VIII-VII a.C.) (Fig. 7). 


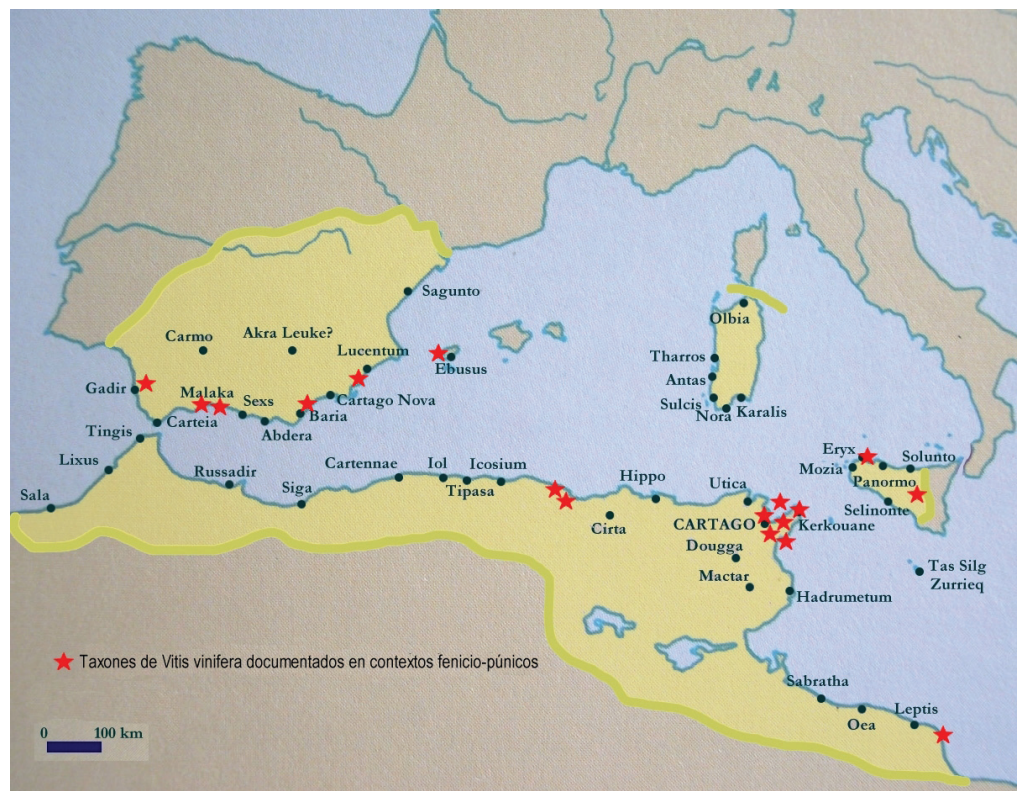

Fig. 7: Mapa del Mediterráneo occidental en época púnica; las estrellas señalan los hallazgos en los análisis de taxones de indicios del cultivo de Vitis vinifera

\begin{tabular}{|l|c|}
\hline \multicolumn{2}{|c|}{$\begin{array}{c}\text { Taxones de Vitis vinifera } \\
\text { (\% sobre el total de especies identificadas) } \\
\text { en yacimientos fenicios de la Pen. Ibérica }\end{array}$} \\
\hline La Fonteta / Rábita (Guardamar) 725-580 a.C. & $2 \%$ \\
\hline La Fonteta / Rábita (Guardamar) 575-525 a.C. & $4 \%$ \\
\hline C. Doña Blanca (Cádiz) 675-600 a.C. & $11,20 \%$ \\
\hline C. Doña Blanca (Cádiz) 600-500 a.C. & $11,58 \%$ \\
\hline Cerro del Villar (Málaga) 750-600 a.C. & $5,28 \%$ \\
\hline Cerro del Villar (Málaga) finales VII a.C. & $21,66 \%$ \\
\hline Cerro del Villar (Málaga) inicios VI a.C. & $4,94 \%$ \\
\hline Villaricos (Almería) 625-500 a.C. & $15,65 \%$ \\
\hline Villaricos (Almería) 500-200 a.C. & $3,08 \%$ \\
\hline Villaricos (Almería) 200-1 a.C. & 0 \\
\hline
\end{tabular}

Fuente: Chamorro (1994); Iborra et alii (2003); López Castro (2003)

En el asentamiento gaditano del Castillo de Doña Blanca (Puerto de Sta. María, Cádiz) se aprecia una presencia significativa de Vitis vinifera ya desde época arcaica 
(principios del siglo VII a.C.) convirtiéndose, además, y si lo comparamos con el resto de especies identificadas, en el elemento más destacado. En los niveles analizados del siglo VI a.C. sucede igualmente; no sólo se mantiene la presencia de vid sino que además se incrementa. Evidentemente estos datos se pueden correlacionar con los restos arqueológicos que se han comentado con anterioridad y que demuestran la existencia de una industria de fabricación del vino en este yacimiento fenicio y púnico ubicado junto a la desembocadura del río Guadalete en la Bahía de Cádiz.

Otro de los yacimientos fenicios de la Península Ibérica que ha dado evidentes muestras de una presencia del cultivo de la vid es el Cerro del Villar (Málaga), fundamentalmente en los niveles estratigráficos fechados a finales del siglo VII a.C., aunque ya aparece en cantidades importantes desde el mismo momento de fundación del enclave fenicio que ocupó un islote fluvial en la costa malagueña (Aubet y Delgado, 2003, 57). Junto con los restos botánicos mencionados, el Cerro del Villar presenta una abundante producción local de vasos contenedores a lo largo del siglo VII a.C. lo que indica que la economía de este asentamiento fenicio estuvo centrada en la comercialización de productos como el aceite y, sobre todo, la uva y el vino (Aubet y Buxó, 1999, 335). En los análisis polínicos realizados en el propio yacimiento no aparece vid ni apenas vegetación en el islote, lo que indica que los campos de cultivo estuvieron alejados del asentamiento, probablemente en alguna zona más propicia de tierra firme. Los datos arqueológicos muestran que sólo a partir del siglo VI a.C. se creó un hinterland agrícola en torno al Cerro del Villar, con un paisaje de granjas rurales que se enmarca en un momento de reordenación del territorio que coincide con la transformación del Cerro del Villar en un enclave dependiente de Malaka. Esta explotación directa ya se puede encajar dentro del nuevo panorama geopolítico dominado por Cartago.

En el caso de la ciudad fenicia de Baria (Villaricos, Almería) ubicada en el sureste ibérico, se ha constatado también el cultivo de Vitis vinifera aunque no desde época arcaica, en el momento de la fundación fenicia y el periodo colonial, sino a partir del 500 a.C. (López Castro, 2003, 98), momento en que la antigua colonia se ubica en la órbita de Cartago. Se trata de una presencia muy significativa la del cultivo de la vid $(15,65 \%)$ sobre el total de especies cultivadas detectadas en las analíticas ${ }^{6}$. Además, el cultivo de la vid en el territorium de la ciudad de Baria coincide en el tiempo con la producción en los talleres locales de ánforas vinarias del tipo 1.2.1.3 (Ramón, $1995,168)$ que manifiestan, por lo tanto, no sólo un consumo local de vino, sino también una más que probable exportación del mismo. La importancia de la explotación agrícola de Baria queda demostrada, además, por la fundación de un santuario extraurbano de carácter rural (López Castro, 2003, 99) en la zona de cultivos a finales del siglo IV a.C. en la que aparecieron terracotas dedicadas a divinidades agrícolas como Demeter-Koré (López Castro, 2004, 80) 7 o el propio Melkart, que también completaba, como es bien sabido, un ciclo anual de muerte y resurrección y que se vinculaba con la fertilidad.

${ }^{6}$ Se trata de la segunda especie más abundante por detrás de los cereales.

7 Para este autor, el culto tributado estaría relacionado con una divinidad ctónica; además, se realizarían ritos propiciatorios para la fertilidad de los campos de cultivo cercanos al asentamiento urbano. 


\section{Comercio del vino y consumo: las ánforas y la problemática de la vajilla de consumo}

Ánforas púnicas han aparecido repartidas en muy diversos lugares de la órbita mediterránea, especialmente en Sicilia y en el Sur de la Península Ibérica desde época antigua. Además, no olvidemos que los centros de producción de este tipo de material cerámico tuvieron un especial desarrollo en el entorno de Cartago, en la Isla de Ibiza y en la Bahía de Cádiz. Es bastante complejo definir las características técnicas de unas piezas que tuvieron una gran diversidad en su procedencia y que se fabricaron desde el siglo VIII hasta el I a.C. Como rasgo general, se puede señalar que se realizaron con un elevado nivel tecnológico, con arcillas bien decantadas y pastas bien cocidas. De todo el grupo producido en el centro del Mediterráneo, las ánforas de Cartago se caracterizaron por unos engobes superficiales blanquecinos y una pasta rosácea muy porosa que ha permitido realizar algunas analíticas para conocer sus contenidos.

Existen grandes problemas para localizar los talleres, fundamentalmente en los periodos más antiguos. Es evidente que la influencia de las ánforas púnicas sobre otras como las ibéricas fue muy fuerte (sobre todo a partir del tipo tradicionalmente denominado Mañá-A). Estos tipos anfóricos se han relacionado, generalmente, con el transporte de vino entre mediados del siglo VI y finales del V a.C. Otros tipos púnicos como la Mañá-Pascual A 4 fueron empleados también para el almacenaje y el transporte de vino (entre el siglo VI y mediados del III a.C.). Las ánforas púnico-ebusitanas aparecen habitualmente en yacimientos catalanes y en el resto de las Baleares, lo que indica un trasiego constante de productos entre la isla y el nordeste peninsular entre el siglo $\mathrm{V}$ y el II a.C., tal y como mencionaremos más adelante.

Las ánforas púnicas han sido consideradas, generalmente, como el medio de transporte de dos productos fundamentalmente: el vino y las salazones de pescado. Algunos de los tipos, además, se pueden relacionar con cada uno de los dos productos; así pues, las piezas con tipos más arcaicos, como las Mañá A1 / R-1 estuvieron dedicados al transporte del vino mientras que las producciones más recientes del llamado "Círculo del Estrecho" (tipos como los Mañá C2 a y C2 b ó la A-4) parece que se dedicaron más al almacenaje y transporte de salsas. A pesar de tales afirmaciones es complicado asignar una especialización determinada para los tipos conocidos en el Mediterráneo Central. El periodo de máxima difusión de los recipientes anfóricos púnicos es el siglo IV a.C., que bien podría corresponderse con un momento de apogeo de la producción vinícola cartaginesa o del consumo de vino en la metrópoli. Pese a la difusión comentada, estos tipos de ánforas suelen aparecer en yacimientos costeros y rara vez aparecen en el interior.

Un problema es que apenas se han realizado análisis de contenidos en las ánforas (Greene, 1996, 317) aprovechando las resinas para efectuar cromatografías (teniendo en cuenta que aquellas ánforas que presentan resinas no han contenido jamás aceite, pues éste las disuelve) y tampoco análisis de taninos ${ }^{8}$. Así, tan sólo tenemos una información parcial de los contenedores, con las tipologías y con algunas marcas, generalmente de alfarero y con algún que otro antropónimo (como Aris o Magón) que bien

\footnotetext{
${ }^{8}$ Sustancias astringentes de carácter vegetal que penetran en las arcillas porosas y que se detectan magníficamente.
} 
podría aludir a algún productor vinícola. Por las tipologías y por la comparación con otras ánforas sobre las que sí se han podido efectuar analíticas, se sabe que estarían preparadas para el transporte interno y de ultramar, y que contendrían generalmente cereales, aceitunas, vino, aceite y miel.

La presencia de algunas cerámicas de transporte exportadas a diversos lugares del Mediterráneo Occidental como la costa catalana (Asensio et alii, 1998, 66) han proporcionado datos para poder hablar de una "cultura del vino" púnica, que desde luego, no es comparable con la desarrollada en el mundo del Egeo y la Magna Grecia o en Etruria. En la costa catalana no sólo han aparecido ánforas vinarias púnico-ebusitanas sino que incluso se llegó a desarrollar un fenómeno de imitación de los contenedores ibicencos realizados con pastas diferentes, interpretado como el resultado de la fundación de pequeñas factorías púnicas en momentos avanzados del siglo IV a.C. (Asensio Vilaró, 2000, 382). Estas piezas, especialmente diseñadas para el transporte marítimo de mercancías líquidas, tenían el vino como su principal contenido (Ramón, 1995, 265-266)

Dejando atrás la discutida vajilla de vino fenicia, tan diferente de la griega (jarra trilobulada y cuencos carenados de engobe rojo), los primeros testimonios de consumo de vino de los que se tiene referencia en Cartago vienen de las excavaciones antiguas en las tumbas denominadas "arcaicas" de la zona de Byrsa, de las que se recuperaron algunos vasos exóticos para beber vino de procedencia griega (kotyles del VIII-VII a.C., Fig. 8). El hecho de no aparecer una vajilla propiamente púnica para vino hace que su consumo supusiese un acto puramente destinado a celebraciones puntuales como los funerales o a otro tipo de actos a los que tendrían acceso tan sólo las clases elevadas, es decir, aquellas que dirigieron las empresas comerciales de ultramar y que controlaron el senado de Cartago (Morel, 1998, 34). En el próximo oriente fenicio sucedió algo similar; el vino era consumido más o menos frecuentemente en función del rango social (Brun, 2003, 112).
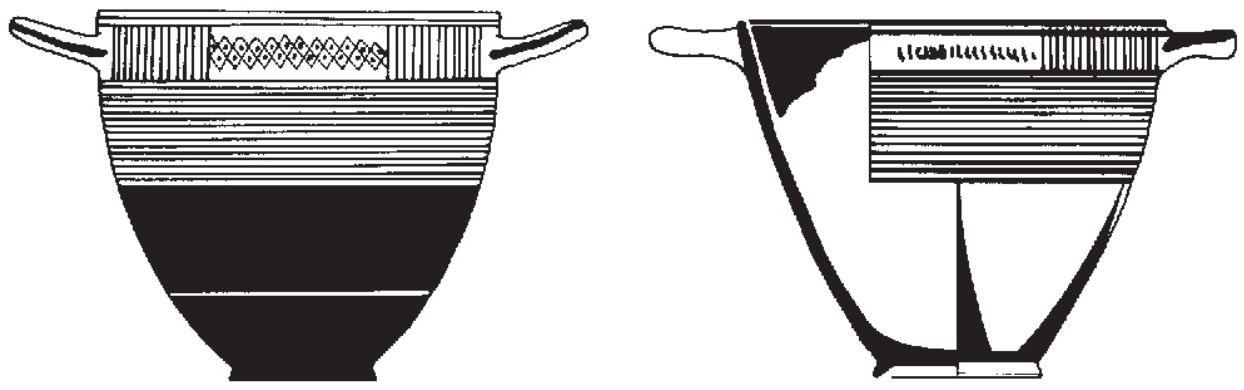

Fig. 8: Copas protocorintias para beber vino. Izquierda, necrópolis fenicia de Almuñécar (Granada), tumba 19 (ca. 700 a.C.) derecha, tumba 195 de Byrsa (Cartago), 690-650 a.C.

Desde el siglo VI a.C. los alfareros cartagineses copiaron muchas formas relacionadas con el consumo del vino, entre éstas destacó la fabricación de ánforas de tipo jonio. En lo concerniente a la vajilla sucedió algo similar, en Cartago y en algunos de 
los principales yacimientos púnicos se imitaron las afamadas piezas griegas en barniz negro, a partir del siglo $\mathrm{V}$ a.C. El máximo desarrollo de la imitación de vajilla fina griega tuvo lugar entre finales del siglo IV a.C. y la destrucción de Cartago, acaecida como hemos visto en el 146 a.C. (Chelbi, 1992,13). Si entre la clásica cerámica púnica no se habían podido identificar formas vinculadas directamente con el consumo del vino no sucedió igual con las imitaciones de cerámicas áticas y campanienses. De todas formas y como se ha adelantado, el consumo del vino parece ser que estaba restringido a las grandes familias, exactamente las mismas a las que estaba dedicada la gran enciclopedia agraria de Magón.

Entre los ajuares de las tumbas y entre las piezas destinadas a la celebración de rituales funerarios aparecen cantidades variables de vasos destinados a contener vino y piezas de vajilla especialmente dedicadas a su consumo. Desde el siglo VII a.C., algunas de las tumbas de la Colina de Byrsa en Cartago albergaron, dentro del conjunto de los ajuares, cerámicas finas para el consumo de líquidos provenientes, en muchos casos, de núcleos urbanos mediterráneos como Corinto o de la costa de Jonia (Morel, 1999, 36 y ss.). Del elenco de cerámicas corintias destacan los kotyles, los aryballos y las copas de formas diversas, mientras que el elenco jonio se caracteriza por las clásicas copas de los tipos B1 y B2. Más adelante, desde el siglo V a.C., junto con las piezas realizadas en talleres púnicos imitando formas griegas, aparecen las clásicas formas áticas para el consumo de vino como los skyphos, los oinokoes y las cráteras. Desde el siglo IV a.C. se documentan piezas para el consumo de vino procedentes de Italia meridional y de Sicilia y, ya en torno al 300 a.C., destaca la presencia de cerámicas del llamado Taller de "Pequeñas Estampillas" con piezas de barniz negro de muy buena calidad con unas decoraciones impresas en el fondo de las piezas. Las formas más características ${ }^{9}$ presentes en el ámbito cartaginés procedentes de este Taller son las páteras y los cuencos de forma simple.
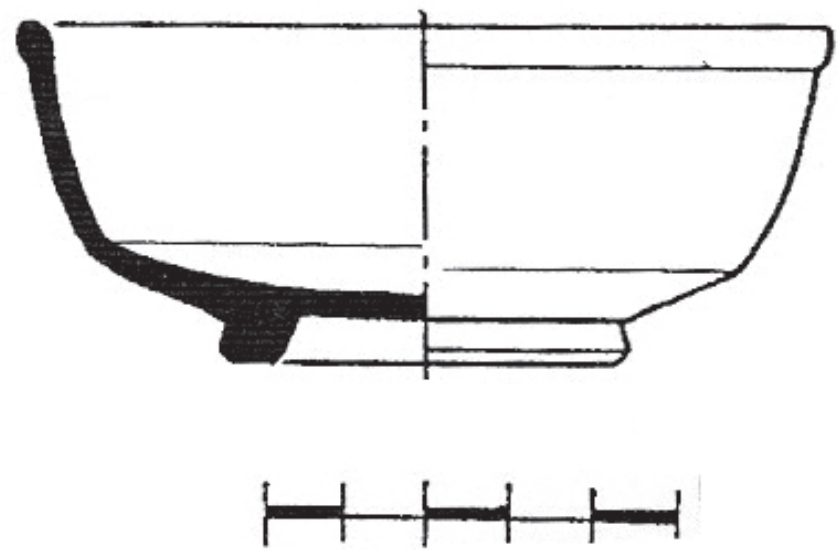

Fig. 9: Cuenco de la forma Byrsa 401 (equivalente a Morel 2640 y Lamboglia 28) realizada en talleres cartagineses (según Guerrero, 1999, 183)

${ }^{9}$ Dentro del elenco dedicado al consumo de bebida. 
Desde el siglo III a.C. comienza la importación en Cartago de las cerámicas suritálicas denominadas "Campaniense A", unas piezas de barniz negro brillante y pastas rojizas fabricadas en talleres de Nápoles desde el siglo III hasta el I a.C. (Morel, 1983, 732 y ss.). En Cartago y en el entorno púnico durante estas mismas fechas se realizaron imitaciones de las formas para el consumo de vino tanto en barniz negro como en barniz rojo. Las primeras, denominadas "cerámicas púnicas de barniz negro" (como por ejemplo los tipos Byrsa $661^{10}$ y Byrsa 401, Fig. 9), constan de unos barnices de escasa calidad, mates y a veces con tonos marrones por cocciones irregulares, que han llegado a duras penas hasta nosotros y presentan unas decoraciones impresas de rosetas y palmetas cuádruples que imitan las piezas griegas mencionadas anteriormente. Uno de los modelos en barniz negro púnico relacionados con el consumo del vino a lo largo del siglo III a.C. es la jarra de pico vertedor, muy estilizada y decorada con guirnaldas esquemáticas realizadas en pintura blanca que decoran la parte interior del borde (Chelbi, 1992). Dentro del segundo grupo destacan las llamadas cerámicas púnicas con barniz tipo "Kouass" elaboradas en este taller del norte de Marruecos y cuya producción se extendió a otras zonas del ámbito cartaginés como la Bahía de Cádiz (Ponsich, 1969; Niveau de Villedary, 2003). Las piezas de Kouass imitaron las clásicas formas campanienses pero mantuvieron el tradicional barniz rojo de origen fenicio.

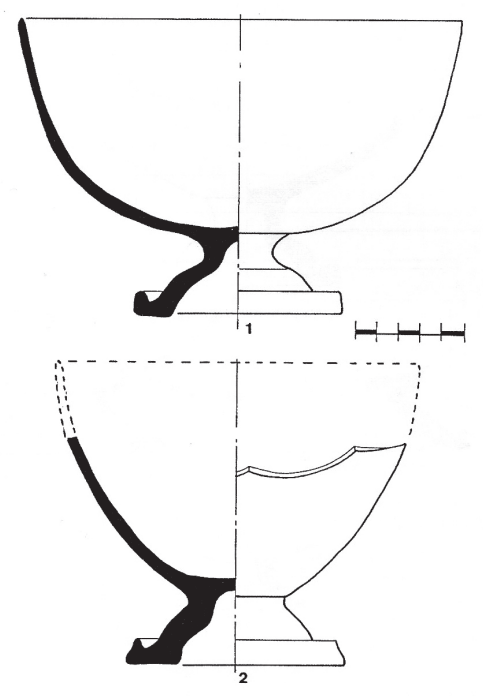

Fig. 10: Cáliz del tipo Lancel 11-12 realizada en talleres de Cartago (según Guerrero, 1999, 185)

10 Identificada últimamente como procedente de los talleres de Cales, al norte de Campania. 
Un tipo muy característico de cerámicas finas de factura cartaginesa es la copa o cáliz Lancel 11-12, destinada, sin duda alguna, al consumo de vino como indica el recubrimiento interno de resina que presentan algunos ejemplares de este tipo hallados en la factoría fenicia de Na Guardis en la isla de Mallorca (Guerrero Ayuso, 1999, 180). Este modelo fue producido en la segunda mitad del siglo III a.C. en alfares de Cartago y tiene escasos paralelos fuera de este ámbito. Lancel, sobre esta copa, ha supuesto que se trató de una copia púnica del kantharos ático (Lancel, 1987, pl. 20), aunque el hallazgo de individuos completos en el fondeadero y el islote de Na Guardis (Fig.10) permiten descartar esta hipótesis y aseguran que se trató de un tipo de recipiente sin asas, destinado al consumo del vino.

\section{Consideraciones finales}

La desigualdad entre el escaso volumen de datos obtenidos a partir de intervenciones arqueológicas y la cantidad de referencias textuales existentes sobre la viticultura en el mundo púnico no tienen por qué llevarnos a la conclusión apriorística de que Cartago y su territorio no tuvieron una cultura del vino desarrollada. Tengamos siempre presente la referencia al mayor de los agrónomos de la antigüedad, Magón y a su origen. Además, pensemos que desde mediados del siglo IV a.C. las ciudades púnicas sufrieron un constante proceso de helenización a todos los niveles, donde la cultura del vino tanto vinculada a la celebración de banquetes funerarios como a otros ritos fúnebres adquirió el mismo desarrollo que en cualquiera de las muchas poleis mediterráneas. Buena parte de los datos que hemos ido introduciendo nos encaminan hacia la demostración de ese proceso.

Cartago, el centro de comercio, el cruce de caminos entre Oriente y Occidente, el lugar por donde circularon gran parte de los productos procedentes del Mediterráneo Oriental y del Egeo, tuvo que tener, por fuerza, una cultura del vino, tanto desde la perspectiva de la producción, como desde la del consumo -al menos entre las élites-. Si como indica S. Lancel (Lancel, 1994, 254) la agronomía púnica fue célebre fundamentalmente por los cultivos arbustivos y la vid, esta celebridad es una razón más que suficiente para plantear el grado de desarrollo que tuvo que tener la viticultura en Cartago y en sus territorios. Además, el amplísimo volumen de ánforas vinarias localizadas en los principales asentamientos púnicos y en aquellos ubicados bajo su influjo político y económico, con sellos en lengua púnica y a veces traducidos al griego, nos llevan a pensar en un comercio internacional de los caldos cartagineses. Pese a esta afirmación, lo exiguo de los datos provoca que debamos quizás pensar más en un mayoritario consumo local del vino púnico.

La falta de investigaciones sobre los ámbitos rurales púnicos, especialmente en el entorno de la capital, que es donde más datos se podrían extraer, es una de las principales causas del estado de desconocimiento, como sucede en las investigaciones que se realizan en la misma zona durante otros periodos históricos, como el tardorromano o el vándalo que hemos denunciado recientemente también en otros foros (Prados Martínez, 2009). Los hallazgos de las villas rurales cercanas a la gran urbe púnica han estado determinados por factores meramente casuales. La fortuna ha de- 
parado la aparición de estas instalaciones agropecuarias, que han sido excavadas con urgencia, ya que ocupaban terrenos que iban a ser edificados. También la tremenda transformación de la ciudad púnica tras la conquista romana hizo que se perdieran, sin duda, numerosos testimonios. Si tan sólo podemos estudiar unos mínimos restos arquitectónicos de lo que fue la gran potencia mediterránea en las exiguas estructuras conservadas en los llamados barrios de "Aníbal" y de "Magón” ¿qué puede haber llegado hasta nosotros de las villas suburbanas? Se trata de una pregunta que ya nos formulábamos hace unos años y que aún sigue sin respuesta (Prados Martínez, 2000, 61). La realidad sigue siendo la misma: es más sencillo conocer muchos aspectos culturales y económicos de Cartago y su civilización cuanto más lejos de la metrópolis investiguemos, lo cual, aparte de acarrear innumerables dificultades, no deja de ser una tremenda contradicción.

\section{Bibliografía}

ACQUARO, E.; AUBET, M.E. y FANTAR, M.H. (1993): Insediamenti fenici e punici nel Mediterraneo occidentale. Roma.

ALVAR, J. y G. WAGNER, C. (1988): "La actividad agrícola en la economía fenicia de la Península Ibérica". Gerión 6. Madrid; pp. 169-185.

AMOURETTI, M.C. (1988): "La viticulture antique méditerranéenne et ses rapports avec la vinification". El Vi a l'Antiguitat. Economia, Producció $i$ Comerç al Mediterrani Occidental. Actas II Col-loqui Internacional d'Arqueologia Romana. Badalona; pp.15-27.

AMOURETTI, M.C. y BRUN, J.P. (1993): La production du vin et de l'huile en Méditeranée. Bulletin de Correspondance Hellénique. Supplément XXVI. École Française d'Athènes. París.

ARTEAGA, O. (1994): “La liga Púnica Gaditana. Aproximación a una visión Histórica Occidental para su contrastación con el desarrollo de la hegemonía cartaginesa en el Mundo Mediterráneo". Cartago, Gadir , Ebusus y la influencia Púnica en los Territorios Hispanos. VIII Jornadas de Arqueología Fenicio-Púnica (Ibiza 1993). Ibiza; pp. 25-59.

ASENSIO I VILARO, D. (2000): “El fenomen de la imitació local d'amfores púnicoebusitanes a la Cossetània Ibérica (segles IV-III a.C.)", III Reunió sobre Economia en el mon Ibèric. Saguntum-Papeles del Laboratorio de Arqueología de Valencia, Extra-3. Valencia; pp. 381-387.

ASENSIO, D.; DEVENAT, L. y SANMARTÍ, J. (1998): "Les impotacions amforals d'origen púnic a la costa de Catalunya en època Tardorepublicana". El Vi a l'Antiguitat. Economia, Producció i Comerç al Mediterrani Occidental. Actas II Col-loqui Internacional d'Arqueologia Romana. Badalona; pp. 66-73. 
AUBET SEMMLER, M.E. y BUXÓ CAPDEVILA, R. (1999): "Los recursos y la economía colonial". En AUBET SEMMLER, M.E., et alii Cerro del Villar I. El Asentamiento fenicio en la desembocadura del rio Guadalhorce y su interacción con el hinterland. Arqueología Monografias, 5. Junta de Andalucía. Sevilla; pp. 334-339.

AUBET SEMMLER, M.E. y DELGADO, A. (2003): "La colonia fenicia del Cerro del Villar y su territorio". En GÓMEZ BELLARD, C. (Ed.) (2003): Ecohistoria del Paisaje Agrario. La agricultura fenicio-púnica en el Mediterráneo. Zaragoza; pp. 57-74.

BENDALA GALÁN, M. (2002-2003): "Cultura agrícola y cultura púnica en la Bética". Homenaje a la Dra. Dña. Encarnación Ruano. Boletín de la Asociación Española de Amigos de la Arqueología, 42. Madrid, pp. 333-342.

BLANCO, J.L. y ROUGGEAU, M. (1999): "Técnicas para la elaboración del vino". El vino en la Antigüedad Romana. Simposio Arqueología del Vino (Jerez, 1996). Madrid; pp.117-128.

BRUN, J-P (2003): Le vin et l'huile dans la Méditerranée antique. Viticulture, oléiculture et procédés de fabrication. París.

BUXÓ CAPDEVILA, R. (1997): Arqueología de las plantas. La explotación económica de las semillas y los frutos en el marco mediterráneo de la Península Ibérica. Barcelona.

CARRILERO MILLÁN, M. y LÓPEZ CASTRO, J.L. (1994): “Ciavieja, un asentamiento de época púnica en el poniente almeriense". El mundo púnico, Historia, sociedad y cultura. Murcia; pp. 251-268.

CATALÁ, M. (1999): "La agricultura: los recursos vegetales a partir de las semillas y frutos". En AUBET SEMMLER, M.E., et alii Cerro del Villar I. El Asentamiento fenicio en la desembocadura del río Guadalhorce y su interacción con el hinterland. Arqueología Monografías, 5. Junta de Andalucía. Sevilla.

CECCHINI, S.M. (1986): "Problèmes et aspects de l'agriculture carthaginoise". Histoire et Archéologie de l'Afrique du Nord (Actes III Colloque International, Montpellier, 1985). París; pp. 108-110.

CELESTINO PÉREZ, S. (1999): (Ed.) El vino en la Antigüedad Romana. Simposio Arqueología del Vino (Jerez, 1996). Madrid.

CHAMORRO, J. (1994): "Flotation strategy: Method and sampling plant dietary resources of Tartessian times at Doña Blanca". En ROSELLÓ, E. y MORALES, A. (Eds.) Castillo de Doña Blanca. Archaeo-environmental investigations in the Bay of Cádiz, Spain (750-500 B.C.). BAR International Series, 593. Oxford; pp. 21-35.

CHELBI, F. (1992): Céramique à vernis noir de Carthage. Túnez. 
CINTAS, P.

(1970): Manuel d'Archeologie Punique I. París.

(1976): Manuel d'Archeologie Punique II. París.

DÍAZ, J.J.; SÁEZ, A.; TOBOSO; E.J.; MONTERO, A. y MONTERO, R. (2002): "Las producciones cerámicas en las Bahías de Algeciras y Cádiz en la antigüedad. Análisis comparativo de sus trayectorias alfareras". Almoraima, 29. VII Jornadas de Historia del Campo de Gibraltar. Algeciras, pp. 123-137.

FANTAR, M.H.

(1984): À Gammarth avant la conquête romaine». Histoire et Archéologie de l'Afrique du Nord (Actes I Colloque I International, Perpignan 1981). París; pp. 3-19.

(1985): Kerkouane, cité punique du Cap Bon (Tunisie) Vol. 2. Túnez. (1996): "De l'agriculture à Carthage". L'Africa Romana. Atti del XII convegno di studio. Olbia; pp.113-121.

FRANKEL, R. (1999): Wine and oil production in Antiquity in Israel and other Mediterranean Countries. Sheffield.

GÓMEZ BELLARD, C.

(1986): "Asentamientos rurales en la Ibiza Púnica". Los fenicios en la Península Ibérica. Sabadell; pp. 177-192.

(2003): "Colonos sin indígenas: El campo ibicenco en época fenicio-púnica". En GÓMEZ BELLARD, C. (Ed.) (2003): Ecohistoria del Paisaje Agrario. La agricultura fenicio-púnica en el Mediterráneo. Zaragoza; pp. 219-235.

GÓMEZ BELLARD, C. (Ed.) (2003): Ecohistoria del Paisaje Agrario. La agricultura fenicio-púnica en el Mediterráneo. Zaragoza.

GÓMEZ BELLARD, C y GUERIN, P. (1994): "Testimonios de la producción vinícola arcaica en L'Alt de Benimaquía (Denia)". Iberos y Griegos, lecturas desde la diversidad, Simposio Internacional (Ampurias 1991). Huelva Arqueológica XIII, 2. Huelva; pp. 9-31.

GÓMEZ BELLARD, C.; GUERIN, P. y PÉREZ JORDÁ, G. (1993): “Témoignage d'une production de vin dans l'Espagne Préromaine". En AMOURETTI, M.C. y BRUN, J.P. (Eds.) La production du vin et de l'huile en Méditeranée. Bulletin de Correspondance Hellénique. Supplément XXVI. École Française d'Athènes. París; pp.379-395.

GONZÁLEZ RODRÍGUEZ, R. (1985): "Excavaciones de Urgencia en el Cerro Naranja (Jerez de la Frontera, Cádiz). Anuario Arqueológico de Andalucía, III. Sevilla; pp. 90-96.

GREENE, J.A. (1996): "The Beginnings of grape cultivation and wine production in Phoenicean / Punic North Africa." En Mc Govern, P.E., Fleming, S.J. y Katz, S.H. (Eds.) The Origins and ancient history of Wine. Amsterdam; pp. 311-322.

GSELL, S. (1918): Histoire Ancienne de l'Afrique du Nord, 4 Vols. París. 
GUERRERO AYUSO, V.M.

(1984): Asentamiento púnico de Na Guardis. Excavaciones Arqueológicas en España, 133. Madrid.

(1999): "Elementos de la vajilla de mesa púnica en Baleares". Actas del XXIV Congreso Nacional de Arqueología, Vol. 3. (Cartagena, 1997). Murcia; pp. 177190.

HELTZER, M. (1993): "Olive and wine production in Phoenicia and in the mediterranean trade". En AMOURETTI, M.C. y BRUN, J.P. (Eds.) La production du vin et de l'huile en Méditeranée. Bulletin de Correspondance Hellénique. Supplément XXVI. École Française d'Athènes. París; pp.49-54.

HEURGON, J. (1976): "L'Agronome Carthaginois Magon et ses traducteurs en latin et en grec". Comptes Rendus de l'Academie des Inscriptions et Belles Lettres. París; pp. 441-456.

IBORRA, M.P.; GRAU, E. y PÉREZ, G. (2003): "Recursos agrícolas y ganaderos en el ámbito fenicio occidental: estado de la cuestión". En GÓMEZ BELLARD, C. (Ed.) Ecohistoria del Paisaje Agrario. La agricultura fenicio-púnica en el Mediterráneo. Zaragoza; pp. 33-55.

LANCEL. S. (1987): "La cerámique punique d'époque hellénistique". Céramiques Hellénistiques et Romaines II. Centre de Recherches d'Histoire Ancienne, Vol. 70. París; pp. 99-137.

LÉQUEMENT, R. (1980): “Le vin africain à l'époque impériale". Antiquités Africaines, 16. París; pp. 185-193.

LEVADOUX, L. (1961): La vigne et sa culture. París.

LIPINSKI, E. Ed. (1992): Dictionnaire de la civilisation phénicienne et punique. París.

LÓPEZ CASTRO, J.L.

(1991): "El imperialismo cartaginés y las ciudades fenicias de la Península Ibérica entre los siglos VI-III a.C.". Studi di Egittologia e Antichità Puniche 9, pp. 87107.

(2003): "Baria y la agricultura fenicia en el extremo occidente". En GÓMEZ BELLARD, C. (Ed.): Ecohistoria del Paisaje Agrario. La agricultura fenicio-púnica en el Mediterráneo. Zaragoza; pp. 93-110.

(2004): "Un santuario rural en Baria (Villaricos, Almería)". En González Blanco, A. et alii (Eds.) Estudios Orientales 5,6. El Mundo Púnico. Religión, Antropología y Cultura Material. Actas II Congreso Internacional de Mundo Púnico, Cartagena 2000. Murcia; pp. 77-89.

LÓPEZ PARDO, F. y SUÁREZ PADILLA, J. (2002): "Traslados de población entre el Norte de África y el sur de la Península Ibérica en los contextos coloniales fenicio y púnico". Gerión, 20/1. Madrid; pp. 113-152. 
MARTIN, R. (1971): Recherches sur les Agronomes Latins et leurs conceptions économiques et sociales. París.

MARTIN-KILCHER, S. (1998): "Le Vin dans la Colonia Iulia Karthago". El Vi a l'Antiguitat. Economia, Producció i Comerç al Mediterrani Occidental. Actas II Col-loqui Internacional d'Arqueologia Romana. Badalona; pp.511-527.

MOREL, J.P.

(1983): "Les importations de Céramiques grecques et italiennes dans le monde punique (V-I Siècles av.J.C.): Révision du matériel et nouveaux documents". Atti I Congresso Internazionale di Studi Fenici e Punici. Roma; pp. 731-740.

(1998): "Que Buvaient les Carthaginois?". El Vi a l'Antiguitat. Economia, Producció i Comerç al Mediterrani Occidental. Actas II Col-loqui Internacional d'Arqueologia Romana. Badalona; pp. 29-38.

(1999): Vie et mort dans la Carthage punique d'après les Fouilles de Byrsa. Túnez.

MORET, P. (1999): "Casas fuertes romanas en la Bética y la Lusitania”. Économie et territoire en Lusitanie romaine. Collection de la Casa de Velázquez, $n^{\circ} 65$. Madrid; pp. 55-89.

NIVEAU DE VILLEDARY, A.M". (2003): Las cerámicas gaditanas "tipo Kouass”. Biblioteca Archaeologica Hispana, 21. Madrid.

PICARD, G. Ch. y C. Ch. (1958): La vie quotidienne à Carthage. París

PONSICH, M. (1969): "Les cerámiques d'imitation: la campanienne de Kouass (Región d'Arcila, Maroc)". Archivo Español de Arqueología, 42. Madrid; pp. 56-80.

PRADOS MARTÍNEZ, F.

(2000): "El desarrollo de la viticultura y el consumo del vino en el ámbito cartaginés". Espacio, Tiempo y Forma, Serie II. Historia Antigua, vol. 13. Madrid; pp. 45-64.

(2002): "Una aproximación a los influjos tecnológicos y tipológicos de la arquitectura púnica en el mundo ibérico". Africa. Serie Revue des Etudes Phéniciennes et Puniques et des Antiquités Libyques XII. Institut National du Patrimoine. Túnez; pp. 79-102.

(2003): Introducción al estudio de la arquitectura púnica. Madrid.

(2004): "¿Almacenes o centros redistribuidores de carácter sacro?. Una reflexión en torno a un modelo arquitectónico tipificado en la Protohistoria mediterránea". En González Blanco, A. et alii (Eds.) Estudios Orientales 5,6. El Mundo Púnico. Religión, Antropología y Cultura Material. Actas II Congreso Internacional de Mundo Púnico, Cartagena 2000. Murcia; pp. 173-180.

(2008): Arquitectura Púnica. Los monumentos funerarios. Anejos de AEspA XLV, Madrid.

(2008b): "El paisaje rural en el territorio de Cartago ante la romanización. Arquitectura militar y funeraria como herramienta de control y coerción social". Los paisajes rurales de la romanización. Arquitectura y explotación del territorio. Mérida-Badajoz (e.p.) 
(2009): "Una aproximación a la cultura del vino en África durante el periodo vándalo: entre Roma y el Islam". El vino en época tardoantigua y medieval. Universidad Autónoma de Madrid. Serie Varia 8, Madrid; pp. 357-373.

PY, M. (Dir.) (1993): Dictionnaire des Céramiques Antiques en Méditerranée nordoccidentale. Lattara 6. Lattes.

PY, M.; ADROHER AUROUX, A.M. y SÁNCHEZ, C. (2001): Corpus des céramiques de l'Âge du Fer de Lattes. 2 Vols. Lattara 14. Lattes.

RAMÓN, J.

(1991): Las ánforas púnicas de Ibiza. Trabajos del Museo Arqueológico de Ibiza, 23. Ibiza.

(1995): Las ánforas fenicio-púnicas del Mediterráneo central y occidental. Collecció Instrumenta, 2. Universitat de Barcelona. Barcelona.

REBUFFAT, R. (1990): "La vigne et le vin au Maroc". Archéologie de la vigne et du vin. Caesarodunum XXIV. París; pp. 219-236.

ROSELlÓ, E. y MORALES, A. (Eds.) Castillo de Doña Blanca. Archaeo-environmental investigations in the Bay of Cádiz, Spain (750-500 B.C.). BAR International Series, 593. Oxford

RUIZ MATA, D. (1995): "El vino en época prerromana en Andalucía occidental”. Arqueología del Vino. Los orígenes del vino en Occidente. Jerez de la Frontera; pp. 157-212.

RUIZ MATA, D. y NIVEAU DE VILLEDARY, A.M"a (1999): "La zona industrial de las Cumbres y la cerámica del siglo III a.n.e. (Castillo de Doña Blanca-El Puerto de Santa María, Cádiz). Actas del XXIV Congreso Nacional de Arqueología, Vol. 3. (Cartagena, 1997). Murcia; pp. 125-131.

RUIZ MATA, D. y PÉREZ, C.J. (1995): El Poblado Fenicio del Castillo de Doña Blanca (El Puerto de Santa María, Cádiz). El Puerto de Santa María.

SÁEZ FERNÁNDEZ, P. (1999): "El vino en las fuentes históricas romanas". El vino en la Antigüedad Romana. Simposio Arqueología del Vino (Jerez, 1996). Madrid; pp. 35-50.

SANMARTI, J. (1991): "El comercio fenicio y púnico en Cataluña". I-IV Jornadas de Arqueología Fenicia-Púnica. Trabajos del Museo Arqueológico de Ibiza, 24. Ibiza; pp. 119-136.

SETHOM, H. (1977): L'Agriculture de la presqu'île du Cap Bon. Túnez.

SETHOM, H. y KASSAB, A. (1981): Les Régions geógraphiques de la Tunisie. Túnez.

TLATI, S-E. (1978): La Carthage Punique. Túnez.

TROUSSET, P. (1995): (Ed.) L'Afrique du Nord antique et Médiévale. Productions et exportations africaines. Actualités archéologiques (VI ${ }^{\mathrm{e}}$ Colloque International sur l'Histoire et l'Archéologie de l'Afrique du Nord, Pau, 1993). París. 
VANDERMERSCH, CH. (1994): Vins et amphores de Grande Grèce et de Sicile. IVe- IIIe s. avant J.-C. Nápoles.

VIDAL GONZÁLEZ, P. (2003): "Ecología y paisaje fenicio-púnico de la isla de Malta". En GÓMEZ BELLARD, C. (Ed.): Ecohistoria del Paisaje Agrario. La agricultura fenicio-púnica en el Mediterráneo. Zaragoza; pp. 255-270.

VV.AA. (1990): Archéologie de la vigne et du vin. Caesarodunum XXIV. París.

ZEIST, W van y BOTTEMA, S. (1982): "Paleobotanical studies of Carthage". Bulletin de Centre d'étude et documentation archéologique de la conservation de Carthage 5. París; pp. 18-22.

ZOHARY, D. (1996): "The domestication of the grapevine Vitis Vinifera L. in the Near East". En Mc Govern, P.E., Fleming, S.J. y Katz, S.H. (Eds.) The Origins and ancient history of Wine. Amsterdam; pp. 23-30. 